\title{
Biology and fertility life table of Eriopis connexa, Harmonia axyridis and Olla v-nigrum (Coleoptera: Coccinellidae)
}

\author{
L. C. F. Zazyckia*, R. E. S. Semedo ${ }^{b}$, A. Silva ${ }^{b}$, A. Z. Bisognin ${ }^{b}$, O. Bernardi ${ }^{a}$, \\ M. S. Garcia ${ }^{c}$ and D. E. Navad

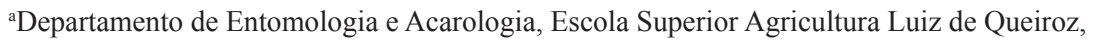 \\ Universidade de São Paulo - USP, Av. Pádua Dias 11, CP 9, CEP 13418-900, Piracicaba, SP, Brazil \\ ${ }^{b}$ Faculdade de Agronomia Eliseu Maciel, Universidade Federal de Pelotas - UFPEL, \\ CP 354, CEP 96010-900, Pelotas, RS, Brazil \\ 'Departamento de Fitossanidade, Faculdade de Agronomia Eliseu Maciel, Universidade Federal de Pelotas - UFPEL, \\ CP 354, CEP 96010-900, Pelotas, RS, Brazil \\ ${ }^{\mathrm{d} E m b r a p a}$ Clima Temperado, CP 403, CEP 96010-971, Pelotas, RS, Brazil \\ *e-mail: luizazazycki@gmail.com
}

Received: March 12, 2014 - Accepted: June 2, 2014 - Distributed: November 30, 2015

(With 2 figures)

\begin{abstract}
The coccinellids Eriopis connexa (Germar), Harmonia axyridis (Pallas) and Olla v-nigrum (Mulsant) are important natural biological control agents. The purpose of this paper was to study the biology and create a fertility life table of these three coccinellid species. For the biology study, 50 insects/species were used and kept in groups of 10 in glass vials $\left(2300 \mathrm{~cm}^{3}\right)$. For the three species studied, the viability of the total cycle varied from 45 to $50 \%$. O. v-nigrum was the species which presented the longest oviposition period. However, H. axiridis demonstrated the best reproductive performance and ability of population growth in each generation. In conclusion, the use of commercially obtained pollen and A. kuenhiella eggs enables the development of coccinellids E. connexa, H. axyridis and O. v-nigrum under laboratory conditions, since the insects completed their biological cycle and originated adults with good reproductive performance.
\end{abstract}

Keywords: biology, coccinellids, biological control.

\section{Biologia e tabela de vida de fertilidade de Eriopis connexa, Harmonia axyridis e Olla v-nigrum (Coleoptera: Coccinellidae)}

\section{Resumo}

Os coccinelídeos Eriopis connexa (Germar), Harmonia axyridis (Pallas) e Olla v-nigrum (Mulsant) são importantes agentes de controle biológico natural. O objetivo deste trabalho foi estudar a biologia e a tabela de vida de fertilidade dessas três espécies de coccinelídeos. Para a biologia foram utilizados 50 insetos/espécie, mantidos em grupo de 10 em recipientes de vidro de $\left(2300 \mathrm{~cm}^{3}\right)$. Para as três espécies estudadas, a viabilidade do ciclo total variou de 45 a $50 \%$. $O$. v-nigrum foi a espécie que apresentou maior período de oviposição. No entanto, H. axiridis foi àquela que demonstrou maior performance reprodutiva e capacidade de aumento populacional a cada geração. Em conclusão, a utilização de pólen comercial e ovos de $A$. kuenhiella possibilita o desenvolvimento dos coccinelídeos E. connexa, H. axyridis e O. v-nigrum em condições de laboratório, pois, os insetos completaram o ciclo biológico e originaram adultos com boa performance reprodutiva.

Palavras-chave: biologia, coccinelídeos, controle biológico.

\section{Introduction}

The Coccinellidae is represented by over 6000 species distributed among 360 different genera. They are predators in both their adult and larval phases, presenting an intense search for food and predatory capacity (Vandenberg, 2002; Olkowski et al., 1990; Oliveira et al., 2004). They are considered important agents in biological control helping to regulate the population of pest insects in many economically important crops (Obrycki and Kring, 1998).

Being predators, coccinellids normally have their nutritional needs met by their prey, especially aphids. However, these are opportunistic and/or generalist predators adopting different strategies to obtain their 
prey, feeding on lepidopteran larvae and other small arthropods. The choosing of other prey occurs when the aphid population is scarce, forcing the predators to search for an alternative food source to guarantee their survival (Sarmento et al., 2007; Evans, 2009).

Being biological control agents with a great capacity for predation, the conservation of coccinellids in crops is extremely important to Integrated Pest Management (IPM). One of the difficulties of using coccinellids for biological control is in related to the maintenance of laboratory populations for their mass rearing. For example, Kalushkov (1998), when evaluating ten species of aphids to discover essential preys for the diet of Adalia bipunctata (L.) (Coleoptera: Coccinellidae), concluded that not all prey species offered as food were adequate for predator growth.

The knowledge about the bioecology of predator that aims at supplying the biological control programs is essential for optimize the mass production of these agents and thus provide insects for releases scheduled in an IPM program such as environmental conditions and diet offered, can influence in the metabolism of coccinellid to provide nutritional support and influence in different vital functions of predator.

Considering this, Rana et al. (2002) when studying the biological aspects of the predator A. bipunctata raised with two aphids species, Acyrtosiphum pisum (Harris) and Aphis fabae Scop.(Aphididae), observed that in temperate regions, rearings are subject to regional climatic changes, which drastically limits rearings due to reduced prey reproduction in the winter.

For the mass rearing of Eriopis connexa (Germar) (Coleoptera: Coccinellidae), 17 different artificial diet combinations were tested, but the predator's biological development was adequate when the diet included eggs from Anagasta kuehniella Zeller (Lepidoptera: Pyralidae) (Silva et al., 2009). In another study different diets were tested, including lyophilized beef, eggs from Ephestia kuehniella Zeller (Lepidoptera: Phycitidae), pollen and cists from Artemia franciscana Kellogg (Branchiopoda: Artemiidae), with the purpose of obtaining a diet for mass rearings of $A$. bipunctata. Adults were produced with all tested diets; however, there was variability in relation to viability and duration of stages and in adult weight. The best development occurred when fed with A. kuehniella eggs (Bonte et al., 2010)

For other coccinellids, variations in biological parameters also was observed when the energy provided by prey is changed, as shown by Bado and Rodriguez (1997) when various species of aphid was used to feed Olla v-nigrum (Mulsant), or even to Santos et al. (2009) which observed reproductive performance of Harmonia axyridis (Pallas) when to fed with aphids and moth eggs.

In this context, knowing the biological aspects of coccinellids is primordial in optimizing laboratory rearings of these insects thus strengthening the strategies of biological control programs. The aim of this paper was to study the biology and make a fertility life table for Eriopis connexa (Germar), H. axyridis (Pallas) and
O. v-nigrum, using commercially obtained pollen and A. kuehniella eggs for food.

\section{Material and Methods}

Adult E. connexa, H. axyridis and $O$. v-nigrum were collected in an experimental peach and strawberry orchard belonging to Embrapa Clima Temperado, Pelotas, Rio Grande do Sul (latitude 31 $42^{\prime}$ 'S and longitude 52 $24^{\prime}$ 'W). After the collection, the insects were transported to a laboratory, kept in plastic cages $(25.5 \mathrm{~cm}$ in length $\times 5.5 \mathrm{~cm}$ in height $\times 15.5 \mathrm{~cm}$ in width), closed at the top with voile to allow for aeration, and maintained in a climatized room at $25 \pm 1^{\circ} \mathrm{C}$, relative humidity of $60 \pm 10 \%$ and a $14 \mathrm{~h}$ photophase. Slightly moist filter paper was used to maintain humidity and toilet paper (odorless) was used as a substrate for oviposition. The cages were checked daily to collect eggs, clean and change food.

The eggs were placed in Petri dishes ( $9 \mathrm{~cm}$ in diameter) containing a disc of slightly moist filter paper. Following eclosion, the larvae were transferred in groups of 10 , with the help of a small brush, to new growth chambers (glass vials $2300 \mathrm{~cm}^{3}$ ), containing a piece of filter paper folded in "zigzag", where $A$. kuehniella eggs were placed. Eggs up to 48 h old were offered to the larvae "ad libitum". In addition, pollen was offered in plastic vials $(2 \mathrm{~cm}$ in diameter $\times 1 \mathrm{~cm}$ in height). The insects were kept in environmental chambers at $25 \pm 1^{\circ} \mathrm{C}$, relative humidity of $60 \pm 10 \%$ and photophase of 14 h. Fifty insects of each species were used; each repetition was composed of 10 insects (kept in glass vials, as previously stated). For each of the species studied, the following parameters were evaluated: duration and viability of egg, larva and pupal stages, egg to adult period, sex, duration of pre-oviposition and oviposition periods, longevity and fertility. The sexual ratio was calculated by the formula: $\mathrm{sr}=$ female/(male + female $)$. The duration and viability of the egg, larva and pupa stages and egg-adult period were determined by daily observations.

The longevity, fecundity and fertility of the three coccinellid species studied were evaluated from the pairing of 20 couples of each species, which were separated in transparent PVC cages $(20 \mathrm{~cm}$ in height $\times 10 \mathrm{~cm}$ in diameter), containing a disc of wet filter paper, pollen and A. kuehniella eggs " ad libitum," along with the substrate for oviposition (toilet paper). The number of eggs and adult mortality were evaluated daily. The second egg laying of each couple was used to determine the embryonic period, the eggs were placed in flat-bottomed glass tubes $(8.5 \times 2.5 \mathrm{~cm})$. A piece of filter paper $(2 \times 1 \mathrm{~cm})$ was placed inside each tube, moistened daily with distilled water, and closed off at the top with plastic film. Eggs laid were counted daily as was the number of larval eclosions.

The experimental design was completely randomized. The data from each biological parameter was tested in relation to homogeneity of variance of error, and with relation to this test, no data transformations were performed. As a method to discern the different treatments, the averages of each biological parameter and each species were 
compared using the Tukey test $(P<0.05)$ in $\mathrm{SAS}^{\circledR}(\mathrm{PROC}$ : ANOVA) (SAS Institute, 2000). The possible deviation in sexual proportions (1 male for 1 female) was compared using the Chi-squared test $\left(\chi^{2}\right)(P<0.05)$ carried out in the $\mathrm{SAS}^{\circledR}$ (PROC FREQ) (SAS Institute, 2000). Additionally, a life and fertility table was made estimating average time between generations $(T)$, the net reproduction rate $\left(R_{o}\right)$, the intrinsic growth rate $\left(r_{m}\right)$ and the finite growth rate $(\lambda)$. The parameters from the life and fertility table and their respective standard errors were estimated via computer program "Lifetable.sas" (Maia et al., 2000) and compared by the bilateral $t$ test $(P<0.05)$ with $\mathrm{SAS}^{\circledR}$ (SAS Institute, 2000).

\section{Results and Discussion}

The duration of the egg phase was significantly higher for $H$. axyridis than for E. connexa and $O$. v-nigrum $(F=604.99$, $\mathrm{df}=2,10, P<0.0001)$. Olla $v$-nigrum was the species with the shortest larval duration $(\approx 7$ days $)$, significantly less than $H$. axyridis and $E$. connexa $(\approx 10$ days $)(F=9.35, \mathrm{df}=2,10$, $P=0.0005)$. On the other hand, the pupal phase duration of the three coccinellid species did not differ significantly from each other $(F=4.25, \mathrm{df}=2,10, P=0.0562)$. The duration of the egg-adult period was longer for $H$. axyridis ( $\approx 18$ days), differing significantly from that of $O$. v-nigrum ( $\approx 16$ days) $(F=6.45, \mathrm{df}=2,10, P=0.0159)$ (Figure $1 \mathrm{~A})$, while $E$. connexa and $O$. v-nigrum had similar durations for the period. The duration of the cycle (larva to adult) of E.connexa when
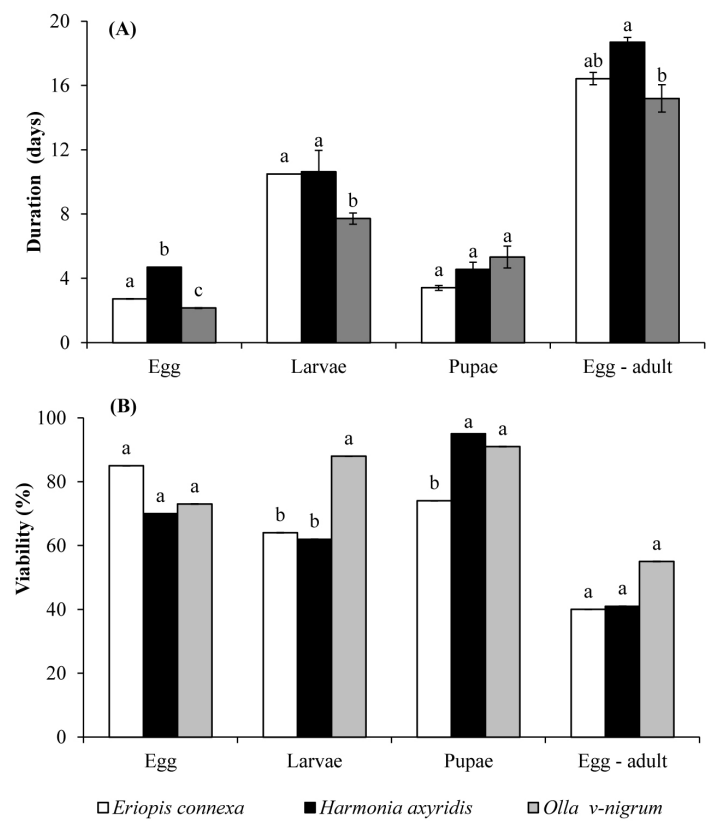

Figure 1. Duration (A) and viability (B) of egg, larval and pupal stages and egg-adult period of E. connexa, H. axyridis and $O$. v-nigrum fed with pollen and $A$. kuehniella eggs $\left(25^{\circ} \mathrm{C} \pm 1\right.$; RH $60 \pm 10 \%$; $12 \mathrm{~h}$ photophase). Means followed by same letter within the stages of development are not significantly different, as assessed by Tukey's test $(P<0.05)$. fed Acyrtosiphum pisum (Harris) (Aphididae) was 14 days at $27^{\circ} \mathrm{C}$, and about 13.4 days while the prey was Schizaphis graminum (Rondani) (Aphididae) (Gyenge et al., 1998), if added to incubation eggs period (2.5 days), the total cycle observed is similar to our results. In contrast, the cycle period (larva to adult) of $O$. v-nigrum was 25 days when the prey was $S$. graminum (Bado and Rodríguez, 1997) in $22 \pm 4^{\circ} \mathrm{C}$ temperature.

Regarding the viability of the different developmental stages of the coccinellids studied, all three species had similar egg viability, superior to $70 \%(F=1.35, \mathrm{df}=2,10$, $P=0.3015$ ) (Figure 1B). In contrast, there were significant differences on the viability of the larval stage $(F=8.29$, $\mathrm{df}=2,10, P=0.0075), O$. v-nigrum had the highest viability (greater than $80 \%$ ), while E. connexa and H. axyridis had similar larval viabilities ( $\approx 65 \%)$. The survival of $H$. axyridis (larval period) was greater than $70 \%$ when fed on eggs and S. graminum + A. kuehniella eggs (Santos et al., 2009). Studying different diets and time to freeze eggs of A. kuehniella offered as food for to E. connexa, Silva et al. (2009) observed that larval viability of predators was above $75 \%$ when food was diet $+A$. kuehniella eggs frozen for 24 hours. For the pupal stage, H. axyridis and O. v-nigrum presented high pupal viability $(>80 \%)$, whereas E. connexa viability $(\approx 70 \%)$ was significantly lower $(F=2.65, \mathrm{df}=2,10, P=0.1194)$. In spite of the differences which occurred in larval and pupal viabilities among the species evaluated, the viability of the total cycle (eggadult) did not differ significantly for all three species, varying from 45 to $55 \%(F=2.46, \mathrm{df}=2,10, P=0.1348)$. According Silva et al. (2009), the viability of $E$. connexa ranges from 25 to $100 \%$ depending on the offered diet (artificial diet + frozen eggs $A$. kuehniella). This may be explained by the fact that working with larvae grouped together in a chamber, in an attempt to come close to the predator's habitat, leads to a competition for space or food. The exploration of the patch by the predator, as well as the levels of resources available, causes a control of the population growth due to the availability of resources and space. This was demonstrated by Grez et al. (2012) while analyzing intraguild competition between Hippodamia variegata (Goeze) (Coccinellidae) and E. connexa, where E. connexa turned out to be more susceptible to the changes in environment and prey size.

The longevity of $O$. v-nigrum males and females was significantly higher than that of $E$. connexa males and females (Figure 2). On the other hand, H. axyridis had longevity similar to that of the other two species studied. O. v-nigrum adults raised on Psylla cubana Crawford (Hemiptera: Psyllidae) presented approximately 60 days of longevity (Chazeau et al., 1991) which reveals the increase in longevity for this species when fed with A. kuehniella eggs. No significant differences among the species studied were seen regarding the pre-oviposition period $(F=0.26$, $\mathrm{df}=2,33, P=0.7708)$. However, $O$. $v$-nigrum females presented a significantly longer oviposition period than $E$. connexa and $H$. axyridis $(F=20.59, \mathrm{df}=2,33, P<0.0001)$. The longest oviposition period was observed for $O$. v-nigrum with 
about 110 days. Similarly to the pre-oviposition period, the post-oviposition periods of all three species were alike $(F=0.98, \mathrm{df}=2,33, P=0.3856)$ (Figure 2).

Regarding reproductive performance, $H$. axyridis had the greatest daily and total fecundity compared to E. connexa and $O$. v-nigrum $(F=3.94, \mathrm{df}=2,32, P=0.0296)$ (Table 1$)$. The daily fecundity of $H$. axyridis was 23 eggs while for E. connexa and O. v-nigrum it was about 11 and 14 eggs day ${ }^{-1}$, respectively. The sex ration was the same for all species $(\approx 0.5)$.

The greater daily oviposition of $H$. axyridis had a direct effect on the total fecundity of this species, which demonstrated the capacity of laying over 1500 eggs in a life cycle, significantly higher than the oviposition capacity of E. connexa and $O$. v-nigrum $(F=6.18, \mathrm{df}=2,38, P=0.0047)$. The variation observed on fecundity and oviposition duration may be directly related to the nutritional input offered by their diet. This has been demonstrated by Santos et al. (2009), observing a change in duration of egg, larva and pupa stages and survival of $H$. axyridis when raised on

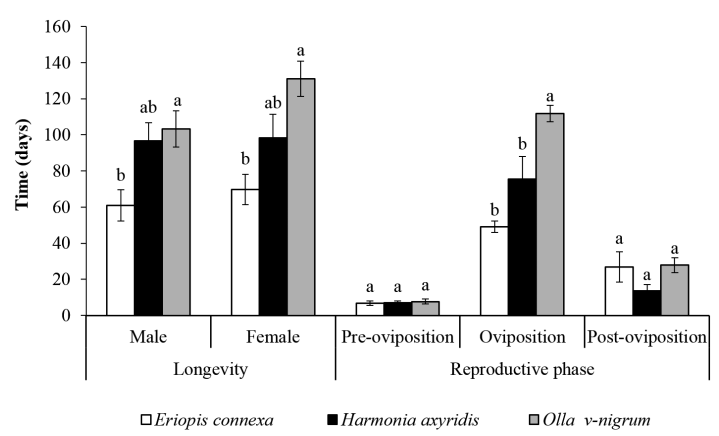

Figure 2. Longevity of males and females and duration of pré-oviposition, oviposition and post-oviposition phases (days) of E. connexa, H. axyridis and $O$. v-nigrum fed with pollen and $A$. kuehniella eggs $\left(25^{\circ} \mathrm{C} \pm 1\right.$; RH $60 \pm 10 \%$; $12 \mathrm{~h}$ photophase). Means followed by same letter within the stages of development are not significantly different, as assessed by Tukey's test $(P<0.05)$.
A. kuehniella eggs and the aphid S. graminum. The direct influence of diet on the daily fecundity of the species was also demonstrated by Rivero et al. (2005) while testing different proportions between artificial and natural food for $O$. v-nigrum. The duration and viability of the larva, pupa and larva-adult stages were different when $E$. connexa was fed with different artificial diets (Silva et al., 2009).

For the parameters on the life table, there were significant differences among the coccinellid species studied. For the mean interval between generations (T), E. connexa and $H$. axyridis presented a similar duration $(\approx 40$ days). In contrast, $O$. v-nigrum presented in average 12 days longer $(T)$. For the net reproductive rate $\left(R_{o}\right)$ after 39.2 days $(T)$ about 346 females are expected to result from each $H$. axyridis female $\left(R_{o}\right)$, while $E$. connexa and O. v-nigrum are capable of generating 126 and 223 females/female/generation, respectively. Besides, the intrinsic growth rate $\left(R_{m}\right)$ was similar between $E$. connexa and $O$. v-nigrum and superior for $H$. axyridis (Table 2). Regarding the finite rate of increase $(\lambda)$, for all species the population presents a growth rate greater than 1 , the population growth may, however, be considered slow. And this slow growth rate may be due to the confinement of these predators with generalist habits. The restraining of these insects to a reduced amount of space could affect their capacity of search and dispersion directly influencing their biological parameters. Another important aspect to be considered is that coccinellids have their population growth in a density-dependent relationship where the predator's growth is intimately related to the prey's population growth - a difficult condition to be simulated in laboratory experiments. This aspect may also affect the bioecology of these insects. Another important aspect noted in this study is that $H$. axyridis demonstrated greater reproductive and population growth capacities which may explain their greater reproductive success in the environment. This species may be displacing other coccinellids as seen by the high number of specimens collected in some years of collecting and the reduced number of other coccinellids

Table 1. Daily and total fecundity of Eriopis connexa, Harmonia axyridis and Olla v-nigrum fed with pollen and Anagasta. kuehniella eggs $\left(25^{\circ} \mathrm{C} \pm 1\right.$; RH $60 \pm 10 \%$; photophase $\left.12 \mathrm{~h}\right)$.

\begin{tabular}{cccc}
\hline Biological parameter & E. connexa $^{(\mathbf{1})}$ & H. axyridis $^{(\mathbf{1})}$ & ${\text { O. } \text { v-nigrum }^{(\mathbf{1})}}^{\text {Daily fecundity }}$ \\
\hline Total fecundity & $14.93 \pm 2.58 \mathrm{~b}$ & $22.92 \pm 2.67 \mathrm{a}$ & $11.51 \pm 1.90 \mathrm{~b}$ \\
\hline
\end{tabular}

Means followed by the same letter in the same line do not differ according to the Tukey's test $(P<0.05) .{ }^{(1)}$ Values represent means \pm SE.

Table 2. Fertility life table of Eriopis connexa, Harmonia axyridis and Olla v-nigrum fed with pollen and Anagasta. Kuehniella eggs $\left(25^{\circ} \mathrm{C} \pm 1\right.$; RH $60 \pm 10 \%$; photophase $\left.12 \mathrm{~h}\right)$.

\begin{tabular}{cccc}
\hline Biological parameter & ${\text { E. } \text { connexa }^{(\mathbf{1})}}^{(1)}$ & H. axyridis $^{(\mathbf{1})}$ & $\boldsymbol{O . ~}_{\boldsymbol{v} \text {-nigrum }}{ }^{(\mathbf{1})}$ \\
\hline$T$ (days) & $38.45 \pm 1.76 \mathrm{a}^{(1)}$ & $39.62 \pm 0.95 \mathrm{a}$ & $50.32 \pm 3.24 \mathrm{~b}$ \\
$\mathrm{R}_{\mathrm{o}}$ & $126.15 \pm 20.48 \mathrm{~b}$ & $346.55 \pm 52.40 \mathrm{a}$ & $223.27 \pm 45.64 \mathrm{ab}$ \\
$\mathrm{R}_{\mathrm{m}}$ & $0.126 \pm 0.006 \mathrm{~b}$ & $0.148 \pm 0.004 \mathrm{a}$ & $0.107 \pm 0.008 \mathrm{~b}$ \\
$\lambda$ & $1.134 \pm 0.006 \mathrm{~b}$ & $1.159 \pm 0.004 \mathrm{a}$ & $1.13 \pm 0.009 \mathrm{c}$ \\
\hline
\end{tabular}

\footnotetext{
Means followed by the same letter in the same line are not significantly different, as assessed by the " $t$ " bilateral test $(P \leq 0.05)$
}

${ }^{(1)}$ Values represent means $\pm \mathrm{SE}$. 
collected in the same areas, since $H$. axyridis presents greater inter and intraguild competition and predation making it an excellent colonizer (Milléo et al., 2008). The polyphagous and voracious $H$. axyridis is also a bigger than most native coccinellid species, granting it a certain advantage in competing for food (Koch, 2003).

Rearing E. connexa, H. axyridis and $O$. v-nigrum with commercial pollen and A. kuenhiella eggs was viable in the laboratory since the insects completed their biological cycle with a relatively high larval viability and originated adults with good reproductive performance. The rearing of coccinellids in laboratory conditions with natural feeding is a viable alternative.

\section{Acknowledgements}

We would like to thanks to Dr. Lúcia Massutti de Almeida and your group (Universidade Federal do Paraná- UFPR) for the confirmation of the Coccinellidae species.

\section{References}

BADO, S.G. and RODRÍGUEZ, S.M., 1997. Aspectos morfologicos, biologicos y de ingesta de Olla v-nigrum (Mulsant) (Coleoptera:Coccinellidae) en Buenos Aires (Argentina). Boletin de Sanidad Vegetal, Plagas, no. 23, pp. 201-207.

BONTE, M., SAMIH, A.M. and DE CLERCQ, P., 2010. Development and reproduction of Adaliabipunctata on factitious and artificial foods. BioControl, vol. 55, no. 4, pp. 485-491. http:// dx.doi.org/10.1007/s10526-010-9266-1.

CHAZEAU, J., BOUYÉ, E. and LARBOGNE, B.L., 1991. Cycle de développement et table de vie d 'Olla v-nigrum (Col: Coccinellidae) ennemi naturel d'Heteropsylla cubana [hom:psyllidae] introdut en nouvelle-celédone. Entomophaga, vol. 36, no. 2, pp. 275-285. http://dx.doi.org/10.1007/BF02374563.

EVANS, E.W., 2009. Lady beetles as predators of insects other than Hemiptera. Biological Control, vol. 51, no. 2, pp. 255-267. http://dx.doi.org/10.1016/j.biocontrol.2009.05.011.

GREZ, A.A., VIERA, B. and SOARES, A.O., 2012. Biotic interactions between Eriopis connexa and Hippodamia variegata, a native and an exotic coccinellid species associated with alfalfa fields in Chile. Entomologia Experimentalis et Applicata, vol. 142, no. 1, pp. 36-44. http://dx.doi.org/10.1111/j.1570-7458.2011.01202.x.

GYENGE, J.E., EDELSTEIN, J.D. and SALTO, C.E., 1998. Efectos de la temperatura y la dieta en la biología de Eriopis connexa (Germar) (Coleoptera: Coccinellidae). Anais da Sociedade Entomológica do Brasil, vol. 27, no. 3, pp. 345-356.

KALUSHKOV, P., 1998. Ten aphid species (Sternorryncha: Aphididae) as prey for Adalia bipunctata (Coleoptera: Coccinellidae). European Journal of Entomology, vol. 95, pp. 343-349.

KOCH, R.L., 2003. The multicolored Asian lady beetle, Harmonia axyridis: a review of its biology, uses in biological control, and non-target impacts. Journal of Insect Science, vol. 32, no. 3, pp. 1-16. http://dx.doi.org/10.1673/031.003.3201. PMid:15841248.

MAIA, H.N.M., LUIZ, A.J. and CAMPANHOLA, C., 2000. Statistical inference on associated fertility life table parameters using jackknife technique: computational aspects. Journal of Economic Entomology, vol. 93, no. 2, pp. 511-518. http://dx.doi. org/10.1603/0022-0493-93.2.511. PMid:10826207.

MILLÉO, J., SOUZA, J.M.T., BARBOLA, I.F. and HUSCH, P.E., 2008. Harmonia axyridis em plantas frutíferas e impacto sobre outros coccinelídeos predadores. Pesquisa Agropecuaria Brasileira, vol. 43, no. 4, pp. 537-540. http://dx.doi.org/10.1590/ S0100-204X2008000400013.

OBRYCKI, J.J. and KRING, T.J., 1998. Predaceous coccinellidae in biological control. Annual Review of Entomology, vol. 43, no. 1, pp. 295-321. http://dx.doi.org/10.1146/annurev.ento.43.1.295. PMid:15012392.

OLIVEIRA, N.C., WILCKEN, C.F. and MATOS, O.C.A., 2004. Ciclo biológico e predação de três espécies de coccinelídeos (Coleoptera: Coccinellidae) sobre o pulgão-gigante-do-pinus Cinara atlantica (Wilson) (Hemiptera: Aphididae). Revista Brasileira de Entomologia, vol. 48, no. 4, pp. 529-533. http:// dx.doi.org/10.1590/S0085-56262004000400016.

OLKOWSKI, W., SHANG, A. and THIERS, P., 1990. Improved biocontrol techniques with lady beetles. IPM Practioner, vol. 12, pp. 1-12.

RANA, J.S., DIXON, A.F.G. and JAROSIK, V., 2002. Costs and benefits of prey specialization in a generalist insect predator. Journal of Animal Ecology, vol. 71, no. 1, pp. 15-22. http://dx.doi. org/10.1046/j.0021-8790.2001.00574.x.

RIVERO, S.H.T., NEVAREZ, G.G. and SANCHEZ, N.C., 2005. Cría de Olla v-nigrum Mulsant (Coleoptera: Coccinellidae) con dieta artificial. Vedalia, vol. 12, no. 1, pp. 91-92.

SANTOS, N.R.P., CIVIDANES, T.M.S., CIVIDANES, F.J., ANJOS, A.C.R. and OLIVEIRA, L.V.L., 2009. Aspectos biológicos de Harmonia axyridis alimentada com duas espécies de presas e predação intraguilda com Eriopis connexa. Pesquisa Agropecuária Brasileira, vol. 44, no. 6, pp. 554-560.

SARMENTO, R.A., PALLINI, A., VENZON, M., SOUZA, O.F.F., MOLINA-RUGAMA, A.J. and OLIVEIRA, C.L., 2007. Functional response of the predator Eriopis connexa (Coleoptera: Coccinellidae) to different prey types. Brazilian Archives of Biology and Technology, vol. 50, no. 1, pp. 121-126. http://dx.doi. org/10.1590/S1516-89132007000100014.

SAS INSTITUTE, 2000. SAS/STAT: Statistical Analysis System: getting started with the SAS learning. Cary: SAS Institute.

SILVA, R.B., ZANUNCIO, J.C., SERRÃO, J.E., LIMA, E.R., FIGUEIREDO, M.L.C. and CRUZ, I., 2009. Suitability of different artificial diets for development and survival of stages of the predaceous ladybeetle Eriopis connexa. Phytoparasitica, vol. 37, no. 2, pp. 115-123. http://dx.doi.org/10.1007/s12600-008-0015-2.

VANDENBERG, N.J., 2002.Coccinellidae latreille 1807. In: R.H. ARNETT JUNIOR, M.C. THOMAS, P.E. SKELLEY and J.H. FRANK, eds. American beetles, polyphaga: scarabaeoidea through curculionoidea. Boca Raton: CRC Press, vol. 2, pp. 371-389. 